\title{
Systematic Review: Efektivitas Siprofloksasin Topikal pada Pengobatan Otitis Media Supuratif Kronik
}

\author{
Anissha Fitry Oktavianita, ${ }^{1}$ Lelly Yuniarti, ${ }^{2}$ Tety H Rahim ${ }^{3}$ \\ ${ }^{1}$ Prodi Pendidikan Dokter, Fakultas Kedokteran, Universitas Islam, Bandung, Indonesia \\ ${ }^{2}$ Departemen Otorhinolaringologi, Fakultas Kedokteran, Rumah Sakit Muhammadiyah, Bandung, Indonesia \\ ${ }^{3}$ Departemen Biokimia, Nutrisi, dan Biomolekul, Fakultas Kedokteran, Universitas Islam, Bandung, Indonesia
}

\begin{abstract}
Abstrak
Otitis media supuratif kronik atau OMSK merupakan proses inflamasi kronik yang terjadi pada telinga bagian tengah yang diakibatkan oleh bakteri, ditandai dengan perforasi membran timpani serta ottorhoea yang terjadi secara terus menerus. Bakteri penyebab paling umum adalah Pseudomonas aeruginosa. Pengobatan OMSK dapat menggunakan antibiotik topikal siprofloksasin. Beberapa penelitian menunjukkan antibiotik topikal lebih efektif dibanding dengan antibiotik sistemik. Tujuan peneltian ini adalah menganalisis efektivitas siprofloksasin topikal pada pengobatan otitis media supuratif kronik. Penelitian ini merupakan systematic review dengan database yang digunakan adalah Google Scholar, Science Direct, Proquest, Springer Link, Cochrane Library, dan EBSCO HOST dengan jumlah artikel yang didapat sebanyak 599 artikel. Hasil skrining pada artikel yang sesuai dengan kriteria inklusi sebanyak 344 artikel dan kriteria eksklusi sebanyak 340 artikel. Setelah dilakukan telaah kritis, artikel yang di-review sebanyak empat artikel. Penelitian dilakukan pada periode Maret-Desember 2020. Hasil telaah dan analisis dari empat artikel menunjukkan bahwa siproflokasin topikal lebih efektif dibanding dengan topikal neomisin, framisetin gramisidin-deksametason (FGD), dan asam borik pada pengobatan otitis media supuratif kronik. Parameter kesembuhan gejala ottorhoea, perforasi membran timpani, serta kualitas pendengaran. Kesimpulan penelitian ini adalah siprofloksasin topikal efektif pada pengobatan otitis media supuratif kronik.
\end{abstract}

Kata kunci: Otitis media supuratif kronik (OMSK), ottorhea, perforasi, siprofloksasin topikal

\section{Systematic Review: Efectiveness of Topical Ciprofloxacin in the Treatment of Chronic Suppurative Otitis Media}

\begin{abstract}
Chronic suppurative otitis media or CSOM is an chronic inflammatory process that occurs in the middle ear, which is caused by bacteria with perforation of the tympanic membrane and the presence of ottorhoea. The most common causative bacteria is Pseudomonas aeruginosa. Topical antibiotic using ciprofloxacin can be used to treat for CSOM. Several studies have shown topical antibiotic to be more effective than systemic antibiotics. The aim of this study was to analyze the effectiveness of ciprofloxacin in the treatment of chronic suppurative otitis media. The study was conducted using systematic review method and database used in this study were Google Scholar, Science Direct, Proquest, Springer Link, Cochrane Library, and EBSCO HOST with 599 articles of journals obtained. The screening result on articles in accordance with the inclusion citeria were 344 articles and the exclusion criteria were 340 articles. The results of critical appraisal as many 4 articles. The study was conducted during March-December 2020. The results of review dan analysis from 4 articles of each study, topical ciprofloxacin was more effective topical neomycin, framycetin gramicidin-dexamethasone (FGD), and boric acid in the treatment of chronic suppurative otitis media. The parameters for relieving of symptomatic symptoms, perforation of tympanic membrane, and hearing quality. The conclusion of this study is that ciprofloxacin topical is more effective in the treatment of chronic suppurative otitis media.
\end{abstract}

Keywords: Chronic suppurative otitis media (CSOM), ciprofloxacin topical, ottorhoea, perforation

Received: 8 ...; Revised: ...; Accepted: ...; Published: ...

Koresponden: Anissha Fitry Oktavianita. Prodi Pendidikan Dokter. Fakultas Kedokteran, Univeristas Islam Bandung, Jln. Tamansari No.22, 40116, Kota Bandung, HP: 085220058423. E-mail: oktavianitaanisshaf@gmail.com 


\section{Pendahuluan}

Otitis media supuratif kronik atau OMSK merupakan proses peradangan pada telinga tengah yang diakibatkan oleh infeksi mukoperiosteum dengan perforasi membran timpani dan keluar sekret yang terjadi terus menerus ataupun hilang timbul yang dapat menyebabkan keadaan patologik yang permanen.1,2 Sekitar 65-300 juta kasus terjadi di seluruh dunia dan $60 \%$ dari kasus mengalami gangguan pendengaran. Populasi dengan prevalensi OMSK tertinggi, yaitu penduduk asli Amerika yang disebut Inuit di Alaska, Kanada, Greenland, Indian Amerika, dan Aborigin Australia (7-46\%). Prevalensi OMSK di negara lain seperti di Kepulauan Pasifik Selatan, Afrika, Korea, India, dan Arab Saudi (1-6\%). . $^{3,4}$

Otitis mediasupuratifkronikmerupakankomplikasi otitis media akut persisten dengan perforasi pada anak yang dapat terjadi tanpa atau dengan kolesteatoma dan tanpa kolesteatoma disebut OMSK tipe banigna, sedangkan OMSK yang disertai kolesteatoma disebut OMSK tipe maligna. ${ }^{2,5}$ Sedangkan OMSK tipe maligna ditandai dengan invasi ke tulang dan mengakibatkan osteomielitis atau destruksi tulang. ${ }^{7}$

Patogen penyebab OMSK biasanya bakteri anaerob atau aerob. ${ }^{9}$ Mikroorganisme aerob: Pseudomonas aeruginosa, Escherichia coli, Streptococus pyogenes, Mirabils proteous, Klebsiella spp, dan mikroorganisme anaerob: Bacteroids, Peptostreptococus, dan Propioni. Jamur juga dapat menyebabkan OMSK, antara lain Candida, Aspergilus, Penicilium, dan Rhizopus. ${ }^{10}$

Patogenesis otitis media supuratif kronik masih kurang dipahami. Interaksi kompleks antara lingkungan, mikrob, dan inang diduga menjadi penyebab OMSK.4,6and can lead to thickening of the middle ear mucosa and mucosal polyps. It usually occurs as a complication of persistent acute otitis media (AOM Biofilm bakteri juga dapat menjadi penyebab OMSK. Biofilm yang resisten terhadap antibiotik menyebabkan bakteri sulit untuk dihilangkan sehingga menyebabkan infeksi berulang. Sitokin yang terlibat dalam patogenesis otits media, antara lain interleukin- 8 (IL-8) yang berperan dalam pengembangan kronisitas otitis media dan pertumbuhan bakteri penyebab OMSK. Peningkatan sitokin lainnya, seperti tumor necrosis factor alfa (TNF- $\alpha$ ) dan interleukin-6 (IL-6) didapatkan di mukosa telinga tengah pasien OMSK yang dapat merusak jaringan serta perubahan otitis media akut menjadi kronik. ${ }^{3}$

Pengobatan otitis media supuratif kronik, di antaranya antiseptik topikal, antibiotik (topikal, oral, atau parenteral), atau operasi. ${ }^{11,12}$ Tujuan pengobatan OMSK adalah membuat telinga menjadi kering yang menghilangkan gejala dan memungkinkan perbaikan membran timpani (terutama jika anak masih sangat muda). ${ }^{5}$ Beberapa penelitian menunjukkan bahwa penggunaan antibiotik topikal lebih efektif dibanding antibiotik sistemik yang dapat dilihat berdasar atas keamanan terapi (efek samping) dan pencegahan infeksi. Penggunaan antibiotik sistemik digunakan apabila telah terjadi komplikasi pada otitis media supuratif kronik., ${ }^{2,13}$ Antibiotik topikal yang sering digunakan salah satunya adalah siprofloksasin.,14 Siprofloksasin adalah jenis antibiotik golongan fluorokuinolon yang paling efektif terhadap mikroorganisme bakteri gram negatif terutama Pseudomonas aeruginosa. $.^{15}, 16,17$ Pada pasien dengan otitis media supuratif kronik diberikan siprofloksasin topikal sehari dua kali sebanyak dua tetes. ${ }^{18,19}$ Tujuan systematic review ini adalah menilai secara sistematis efektivitas siprofloksasin topikal pada pengobatan otitis media supuratif kronik.

\section{Metode}

Fokus utama penelitian adalah efektivitas siprofloksasin topikal pada pengobatan otitis media supuratif kronik.

Data diekstraksi melalui proses seleksi tiga tahap. Di tahap pertama, dilakukan pencarian data pada database Google Scholar dengan kata kunci ciprofloxacin AND (ear drop OR ototopical OR topical) AND "chronic suppurative otitis media" AND "randomized controlled trial". Pada database Science Direct dan Springer Link menggunakan kata kunci ciprofloxacin AND (ear drop OR ototopical OR topical) AND chronic suppurative otitis media AND randomized controlled trial. Pada database Proquest menggunakan kata kunci ciprofloxacin AND (ear drop OR ototopical OR topical) AND chronic suppurative otitis media. Pada database lain, yaitu Cochrane Library dan EBSCO HOST menggunakan kata kunci ciprofloxacin AND chronic suppurative otitis media AND randomized controlled trial. Di tahap kedua, judul dan abstrak ditinjau berdasarkan kriteria inklusi. Kriteria inklusi pada penelitian ini adalah artikel penelitian yang telah dipublikasi pada jurnal internasional yang berkaitan dengan efektivitas siprofloksasin topikal pada pengobatan otitis media supuratif kronik dengan database yang digunakan adalah Google Scholar, Science Direct, Proquest, Springer Link, Cochrane Library, dan EBSCO HOST; artikel penelitian yang diterbitkan dalam rentang waktu tahun 2001-2020; tipe artikel penelitian randomized controlled trial (RCT); artikel penelitian yang dapat diakses secara penuh (full text); dan artikel berbahasa Inggris. Di tahap ketiga, kriteria eksklusi digunakan untuk menyaring artikel lebih lanjut. Kriteria eksklusi pada penelitian ini adalah ketidaksesuaian antara judul artikel dan abstrak. Pemeriksaan kesesuaian abstrak berdasar atas PICOS; artikel lengkap tidak dapat diakses; dan artikel yang duplikasi pada database lainnya. Artikel yang didapatkan dipilih berdasar atas kesesuaian dengan kriteria PICOS: Population (pasien dengan otitis media supuratif kronik), Intervention (pemberian antibiotik topikal golongan kedua flurokuinolon, yaitu siprofloksasin), Comparison (kelompok yang diberi selain siprofloksasin topikal, Outcome (keberhasilan penggunaan siprofloksasin pada pengobatan otitis media supuratif kronik), dan Study (Randomized Controlled Trial).

Penilaian kualitas atau kelayakan pada penelitian ini didasarkan pada kriteria inklusi dan eksklusi penelitian. Telaah kritis dilakukan oleh dua orang dengan menggunakan checklist yang sesuai dengan jenis penelitian, yaitu randomized controlled trial (RCT) berdasar atas https://joannabriggs.org/ebp/ critical_appraisal_tools. 
Semua data berupa artikel penelitian yang sesuai dengan kriteria kelayakan yang di-review dan dianalisis secara kualitatif. Hasil keseluruhan artikel yang memenuhi syarat untuk di-review sebanyak 4 (empat) artikel.

\section{Hasil}

Hasil pencarian data mengenai efektivitas siprofloksasin topikal pada pengobatan otitis media supuratif kronik pada satu database, yaitu Google Scholar sebanyak 133 artikel, Science Direct sebanyak 133 artikel, Proquest sebanyak 150 artikel, Springer Link sebanyak 41 artikel, Cochrane Library sebanyak 20 artikel, dan EBSCO HOST sebanyak 88 artikel. Artikel yang sesuai dengan kriteria inklusi sebanyak 344 artikel dan yang termasuk dalam kriteria eksklusi sebanyak 309 artikel. Hasil uji kelayakan berdasar atas PICOS sebanyak 4 artikel. Setelah dilakukan critical appraisal semua artikel dinyatakan layak juga sebanyak 4 artikel. Diagram PRISMA dapat dilihat pada Gambar. 1.
Terdapat empat artikel penelitian yang telah direview sebagai berikut.

Comparison between the efficacy of topical ciprofloxacin with neomycin in the management of chronic suppurative otitis media. (Siddique et al. 2020). Tujuan penelitian ini membandingkan efektivitas topikal siprofloksasin dengan neomisin pada pengobatan otitis media supuratif kronik. Hasil penelitian menunjukkan bahwa pemberian siprofloksasin topikal lebih efektif dibanding dengan topikal neomisin untuk mengontrol discharge dan kongesti pada otitis media supuratif kronik. Siprofloksasin dapat ditoleransi dengan baik dengan efek samping minimal sehingga hal tersebut menujukkan bahwa siprofloksasin dapat dianggap sebagai pilihan awal topikal antibiotik karena mempunyai spektrum yang luas dan profil efek samping rendah dengan toksisitas minimal; ${ }^{20}$

Effectiveness of ototopical antibiotics for chronic supurative otitis media in Abroiginal children: a community-based, multicentre, double-blind randomised controlled trial (Couzos et al. 2020). Tujuan penelitian ini adalah

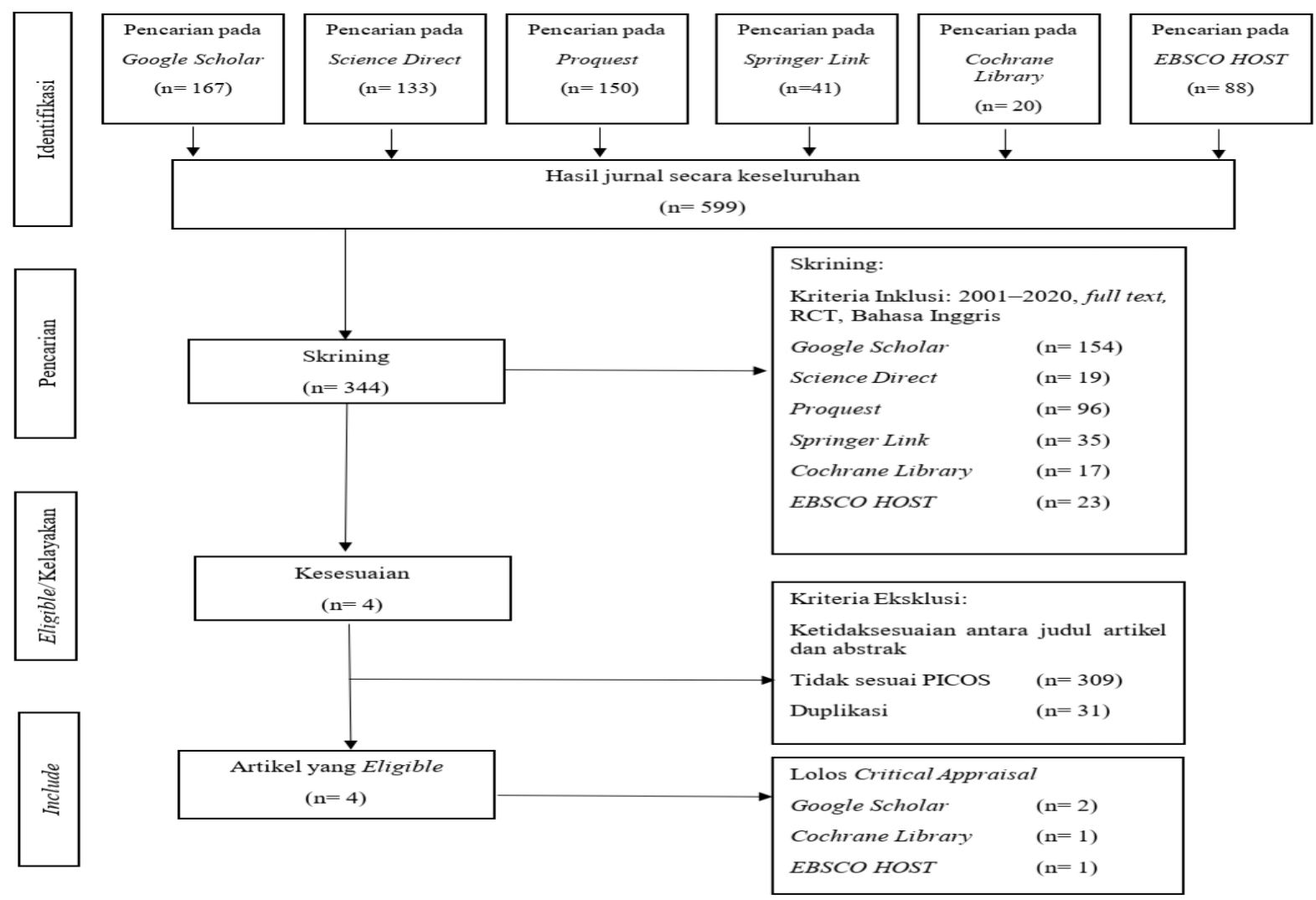


membandingkan efektivitas siprofloksasin ototopikal (o,3\%;siprofloksasin) dengan framisetin (0,5\%), gramisidin, deksametason tetes telinga ( 5 tetes 2 kali sehari untuk 9 hari) bersamaan dengan povidoneiodine $(0,5 \%)$ untuk membersihkan telinga sebagai pengobatan untuk otitis media supuratif kronik pada anak Aborigin. Hasil penelitian menunjukkan bahwa penyembuhan OMSK terjadi pada 64\% (siprofloksasin, $76,4 \%$;framisetin gramisidi-deksametason, 51,8\%), dengan peningkatan yang signifikan pada kelompok siprofloksasin $(\mathrm{P}=0,009$, perbedaan absolut $24,6 \%$ [95\% CI, 15,8-33,4\%]). Pembersihan telinga sebanyak 2 kali sehari dan pengobatan siprofloksasin topikal lebih efektif pada penyembuhan otitis media supuratif kronik; ${ }^{21}$

Topical ciprofloxin versus topical framycetingramicidin-dexamethasone in Australian Aboriginal children with recently treated chronic suppurative otitis media (Leach et al. 2018). Penelitian ini bertujuan membandingkan siprofloksasin topikal dengan framycetin-gramicidin-dexamethasone (FGD) topikal pada pengobatan otitis media supuratif kronik. Hasil penelitian menunjukkan bahwa penyembuhan membran timpani terjadi pada satu dari 50 anak di kelompok siprofloksasin dan tidak satupun dari 47 anak dalam kelompok FGD mengalami penyembuhan. Hal tersebut menunjukkan bahwa penggunaan siprofloksasin topikal lebih efektif dibanding dengan topikal framycetin gramicidin-dexamethasone (FGD) dalam proses penyembuhan otitis media supuratif kronik; ${ }^{22}$

Topical quinolone vs. antiseptic for treating chronic suppurative otitis media: a randomized controlled trial (Macfadyen et al. 2016). Penelitian ini bertujuan membandingkan antibiotik kuinolon topikal (siprofloksasin) dengan antiseptik topikal (asam borik) untuk pengobatan otitis media supuratif kronik pada anak. Hasil penelitian menunjukkan selama 2 minggu, discharge dapat dihilangkan pada anak yang diberi siprofloksasin dan anak yang diberikan asam borik. Efek ini juga signifikan pada waktu 4 minggu dan siprofloksasin dikaitkan dengan tanda pendengaran yang lebih baik pada kunjungan kedua. ${ }^{23}$

Hasil uji kelayakan artikel didapatkan bahwa dari 4 artikel yang di-review, semua artikel memiliki desain penelitian randomized controlled trial. Hasil systematic review efektivitas siprofloksasin topikal pada pengobatan otitis media supuratif kronik dapat dilihat pada Tabel 1.

Tabel 1 Hasil Systematic review: Efektivitas Siprofloksasin Topikal pada Pengobatan Otitis Media Supuratif Kronik

\begin{tabular}{|c|c|c|c|c|c|c|}
\hline No & $\begin{array}{l}\text { Judul, waktu } \\
\text { dan tempat }\end{array}$ & Tujuan & Desain Penelitian & $\begin{array}{c}\text { Metode } \\
\text { Pengukuran }\end{array}$ & $\begin{array}{c}\text { Teknik } \\
\text { Analisis }\end{array}$ & Hasil \\
\hline 1. & $\begin{array}{l}\text { Comparison } \\
\text { between the } \\
\text { efficacy of topical } \\
\text { ciprofloxacin } \\
\text { with neomycin in } \\
\text { the management } \\
\text { of chronic } \\
\text { suppurative otitis } \\
\text { media } \\
2016 \text {. } \\
\text { Combined Militar }\end{array}$ & $\begin{array}{l}\text { Membandingkan } \\
\text { efektivitas } \\
\text { siprofloksasin } \\
\text { topikal dengan } \\
\text { neomisin pada } \\
\text { pengobatan otitis } \\
\text { media supuratif } \\
\text { kronik }\end{array}$ & $\begin{array}{l}\text { Randomized controlled } \\
\text { trial }(\text { RCT) } \\
186 \text { Sampel } \\
\text { Pada kelompok } 1 \\
\text { diberikan obat tetes } \\
\text { telinga siprofloksasin } \\
\text { ( } 3 \text { tetes Sipoteks) dan } \\
\text { pada kelompok } 2 \\
\text { diberikan obat tetes } \\
\text { telinga neomisin (3 } \\
\text { tetes neosporin }\end{array}$ & $\begin{array}{l}\text { Pemeriksaan } \\
\text { telinga pasien: } \\
\text { tidak ada } \\
\text { discharge, } \\
\text { discharge }\end{array}$ & $\begin{array}{l}\text { Chi square test } \\
\text { dengan nilai } \\
\mathrm{P}<0,05 \text { yang } \\
\text { menunjukkan } \\
\text { adanya } \\
\text { perbedaan antara } \\
\text { pemberian } \\
\text { siprofloksasin } \\
\text { topikal dan } \\
\text { neomisin topikal }\end{array}$ & $\begin{array}{l}\text { Pemberian siprofloksasin } \\
\text { topikal lebih efektif } \\
\text { dibandingkan dengan } \\
\text { topikal neomisin untuk } \\
\text { mengontrol discharge } \\
\text { dan kongesti pada otitis } \\
\text { media supuratif kronik. }\end{array}$ \\
\hline
\end{tabular}

Hospital (CMH),

Peshawar

\begin{tabular}{|c|c|c|c|c|}
\hline $\begin{array}{l}\text { Effectiveness } \\
\text { of ototopical } \\
\text { antibiotics for } \\
\text { chronic supurative } \\
\text { otitis media } \\
\text { in Abroiginal } \\
\text { children: a } \\
\text { community-based, } \\
\text { multicentre, } \\
\text { double-blind } \\
\text { randomised } \\
\text { controlled trial } \\
2003 \\
\text { Australia Utara }\end{array}$ & $\begin{array}{l}\text { membandingkan } \\
\text { efektivitas } \\
\text { siprofloksasin } \\
\text { ototopikal (o,3\%; } \\
\text { CIP) dengan } \\
\text { framisetin } \\
\text { (o,5\%), } \\
\text { gramisidin, } \\
\text { deksametason } \\
\text { tetes telinga } \\
\text { ( } 5 \text { tetes } 2 \text { kali } \\
\text { sehari untuk } 9 \\
\text { hari) bersamaan } \\
\text { dengan } \\
\text { povidone-iodine }\end{array}$ & $\begin{array}{l}\text { Randomized controlled } \\
\text { trial (RCT) } 111 \text { Sampel } \\
\text { Siprofloksasin } \\
\text {; (o,3\%, Siloksan, } \\
\text { Alcon Labs Ptry } \\
\text { Ltd) atau framisetin } \\
\text { (o,5\%), gramsidin } \\
\text { dan deksametason } \\
\text { (Sofradeks, Aventis } \\
\text { Pharma Pty Ltd - } 5 \\
\text { tetes } 2 \text { kali sehari } \\
\text { selama } 9 \text { hari) }\end{array}$ & $\begin{array}{l}\text { Otoskopi untuk } \\
\text { melihat adanya } \\
\text { otorrhea, } \\
\text { pengambilan } \\
\text { sampel } \\
\text { discharge untuk } \\
\text { pemeriksaan } \\
\text { bakteriologi, } \\
\text { mengukur } \\
\text { perforasi } \\
\text { membran } \\
\text { timpani, dan } \\
\text { dilakukan pure- } \\
\text { tone audiometry. }\end{array}$ & $\begin{array}{l}\text { Statistik } \\
\text { Univariat } \\
\text { Statistik Bivariat } \\
\text { versi eksak x2- } \\
\text { tipe tes. Hasil } \\
\text { menunjukkan } \\
\text { nilai P <0,05. } \\
\text { Statistik } \\
\text { Multivariat }\end{array}$ \\
\hline
\end{tabular}

pengobatan dengan siprofloksasin topikal lebih efektif pada penyembuhan otitis media supuratif kroni. 


\begin{tabular}{|c|c|c|c|c|c|}
\hline $\begin{array}{l}\text { Topical ciprofloxin } \\
\text { versus topical } \\
\text { framycetin- } \\
\text { gramicidin- } \\
\text { dexamethasone } \\
\text { in Australian } \\
\text { Aboriginal children } \\
\text { with recently } \\
\text { treated chronic } \\
\text { suppurative otitis } \\
\text { media } 2008 \\
\text { Australia }\end{array}$ & $\begin{array}{l}\text { Untuk } \\
\text { membandingkan } \\
\text { siprofloksasin } \\
\text { topikal dengan } \\
\text { framycetin- } \\
\text { gramicidin- } \\
\text { dexamethasone } \\
\text { (FGD) topikal } \\
\text { pada pengobatan } \\
\text { otitis media } \\
\text { supuratif kronik }\end{array}$ & $\begin{array}{l}\text { Randomized controlled } \\
\text { trial (RCT) } \\
97 \text { sampel Diberikan } \\
\text { siprofloksasin topikal } \\
\text { (Siloksin) atau FGD } \\
\text { (Sofradeks) } \\
\end{array}$ & $\begin{array}{l}\text { Pemeriksaan } \\
\text { klinis dan } \\
\text { mikrobiologi. } \\
\text { Melihat adanya } \\
\text { ottorhoea dan } \\
\text { ukuran perforasi } \\
\text { membran } \\
\text { timpani. }\end{array}$ & $\begin{array}{l}\text { Proporsi anak } \\
\text { yang mengalami } \\
\text { kegagalan } \\
\text { peneymebuhan } \\
\text { dengan FGD } \\
\text { sekitar 90\%. }\end{array}$ & $\begin{array}{l}\text { Pengobatan dengan } \\
\text { topikal siprofloksasin } \\
\text { lebih efektif } \\
\text { dibandingkan topikal } \\
\text { FGD }\end{array}$ \\
\hline $\begin{array}{l}\text { 4opical quinolone } \\
\text { vs. antiseptic for } \\
\text { treating chronic } \\
\text { suppurative } \\
\text { otitis media: } \\
\text { a randomized } \\
\text { controlled trial } \\
\text { 20o5 } \\
\text { District Kisumu, } \\
\text { Kenya Barat }\end{array}$ & $\begin{array}{l}\text { membandingkan } \\
\text { antibiotik } \\
\text { kuinolon topikal } \\
\text { (siprofloksasin) } \\
\text { dengan } \\
\text { antiseptik } \\
\text { topikal (asam } \\
\text { borik) untuk } \\
\text { pengobatan otitis } \\
\text { media supuratif } \\
\text { kronik pada anak }\end{array}$ & $\begin{array}{l}\text { Randomized controlled } \\
\text { trial (RCT) } \\
427 \text { siprofloksasin } \\
\text { (Ciloksan o,3\%; Alkon) } \\
\text { atau dengan obat } \\
\text { tetes telinga antiseptik } \\
\text { (Asam borik } 2 \% \text { dalam } \\
45 \% \text { alkohol) }\end{array}$ & $\begin{array}{l}\text { Melihat adanya } \\
\text { discharge, } \\
\text { perforasi } \\
\text { membran } \\
\text { timpani, dan } \\
\text { ambang batas } \\
\text { pendengaran } \\
\text { menggunakan } \\
\text { pure-tone } \\
\text { audiometry. }\end{array}$ & $\begin{array}{l}\text { Person's chi- } \\
\text { square dan } \\
\text { ANCOVA }\end{array}$ & $\begin{array}{l}\text { Pemberian topikal } \\
\text { siprofloksasin lebih } \\
\text { efektif dibandingan } \\
\text { dengan asam borik dan } \\
\text { alkohol pada pengobatan } \\
\text { otitis media supuratif } \\
\text { kronik. }\end{array}$ \\
\hline
\end{tabular}

\section{Pembahasan}

Berdasar atas 4 artikel yang telah di-review menunjukkan bahwa penggunaan siprofloksasin topikal lebih efektif dibanding dengan antibiotik topikal lain pada pengobatan otitis media supuratif kronik. Pasien otitis media supuratif kronik sering kali lebih merespons terhadap antibiotik yang bersifat topikal dibandingdengan sistemik. Antibiotik topikal menggunakan konsentrasi yang lebih besar pada jaringan yang ditargetkan dibanding dengan antibiotik sistemik. ${ }^{20}$ Siprofloksasin merupakan generasi kedua kunionolon FDA yang disetujui untuk pengobatan OMSK pada orang dewasa. Siprofloksasin ototopikal memiliki keunggulan dibanding dengan neomisinkarena memiliki pH 6,5 sehingga tidak mengganggu administrasi serta penyerapan sistemik. Siprofloksasin topikal menunjukkan kemungkinan induksi toksisitas sistemik rendah sehingga efek samping siprofloksasin topikal ringan. Pada penelitian Siddique et al. pada tahun 2016 juga menunjukkan bahwa tidak ada satu pasien pun yang mengeluh gangguan pendengaran yang berat, pusing, vertigo, mual, dan muntah selama atau setelah masa pengobatan. $^{20}$

Menurut penelitian Kutz pada tahun 2013 kombinasi siprofloksasin dan deksametason dapat dijadikan pengobatan lini pertama ottorhea dengan perforasi membran timpani. Sediaan tersebut dapat membunuh dan melawan bakteri penyebab OMSK dan mengurangi pembentukan jaringan granulasi. ${ }^{24}$ Penelitian lain yang menyatakan bahwa penggunaan siprofloksasin topikal lebih efektif. Pada tahun 2004 menerangkan bahwa profil keamanan obat untuk OMSK yang baik adalah jenis kuinolon dengan penggunaan ototopikal. Efek samping pada yang ditemukan pada lebih tinggi terkait dengan nyeri telinga, iritasi, dan pendarahan dengan penggunaan asam borik dalam alkohol. Hal ini dimungkinkan karena alkohol dapat menyebabkan rasa perih. ${ }^{23}$
Selain itu, JM juga pernah melakukan penelitian pada tahun 2000 yang mengungkapkan bahwa antibiotik topikal lebih unggul dari agen sistemik, apalagi topikal fluorokuinolon lebih efektif dibandingkan antibiotik topikal lainnya. ${ }^{20}$

Pseudomonas aeruginosa adalah patogen paling umum yang menyebabkan OMSK. ${ }^{3}$ Pseudomonas aeruginosa ditemukan sekitar 22-44\% pada pasien OMSK. Staphylococcus aureus merupakan organisme tersering kedua pada $17-37 \%$ pasien OMSK. ${ }^{3}$ Pseudomonas aeruginosa dan Staphylococcus aureus ditemukan di kulit liang telinga yang dapat berkembang karena kerusakan mukosa telinga tengah, peradangan, laserasi, atau kelembapan yang tinggi. Mikroorganisme ini dapat masuk ke dalam telinga bagian tengah melalui perforasi kronik. ${ }^{2}$ Sejumlah uji klinis terhadap antibiotik kuinolon menunjukkan bahwa siprofloksasin memiliki aktivitas melawan Pseudomonas aeruginosa dengan angka kesembuhan yang tinggi. Antibiotik topikal kuinolon lebih efektif daripada antibiotik kuinolon sistemik saat pembersihan cairan setelah 1-2 minggu. ${ }^{22}$ Mekanisme kerja siprofloksasin terhadap bakteri penyebab OMSK, yaitu masuk ke dalam sel bakteri melalui saluran porin dan menunjukkan efek antimikrob pada DNA girase (bakteri topoisomerase II) dan bakteri topoisomerase IV. Inhibisi topoisomerase IV berdampak pada stabilisasi kromosom selama pembelahan sel sehingga mengganggu pemisahan DNA yang baru direplikasi. Pada organisme gram negatif (misalnya, Pseudomonas aeruginosa) penghambatan DNA girase lebih signifikan daripada topoisomerase IV. ${ }^{17}$

Penelitian Uden et al. pada tahun 2018 menunjukkan antibiotik siprofloksasin memiliki resistensi sekitar 6,3-0,8\% dan sensitivitas 92,1\% terhadap Pseudomonas aeruginosa. Hal ini menunjukkan bahwa siprofloksasin efektif terhadap bakteri penyebab otitis media supuratif kronik. ${ }^{25}$

Keterbatasan penelitian ini adalah data penelitian 
mengenai efektivitas siprofloksasin topikal pada pengobatan otitis media supuratif kronik sangat terbatas. Keterbatasan lainnya, yaitu tidak dilakukan metaanalisis hanya dilakukan analisis secara kualitatif.

\section{Kesimpulan}

Berdasar atas hasil pencarian data 4 artikel yang telah di-review, dapat ditarik kesimpulan bahwa penggunaan siprofloksasin topikal lebih efektif dibanding dengan antibiotik topikal, yaitu topikal neomisin, framisetin gramisidin-deksametason (FGD), dan asam aborik pada pengobatan otitis media supuratif kronik.

Saran yang dapat diberikan peneliti berdasar atas penelitian yang dilakukan, penelitian lebih lanjut dengan metode meta-analysis dan hasil penelitian ini diharapkan menjadi pedoman penggunaan siprofloksasin topikal pada pengobatan otitis media supuratif kronik.

\section{Konflik Kepentingan}

Tim peneliti tidak memiliki konflik kepentingan dalam penelitian ini.

\section{Ucapan Terima Kasih}

Peneliti ucapkan terima kasih kepada Fakultas Kedokteran Universitas Islam Bandung dan tim skripsi yang telah mendukung dan membantu dalam penulisan artikel penelitian ini.

\section{Daftar Pustaka}

1. Pasyah MF, Wijana. Otitis media supuratif kronik pada anak. GMHC. 2016;4(1):1.

2. Boesoirie SF, Mahdiani S, Yunard A, Aziza Y. Sistem indra T.H.T.K.L dan mata. Dalam: Mahdiani S, Dewi YA, penyunting. Otitis media supuratif kronis (OMSK). Edisi ke-1. Singapura. Elsevier; 2020. hlm. 321-33.

3. Mittal R, Lisi C V, Gerring R, Mittal J, Mathee $\mathrm{K}$, Narasimhan G, dkk. Current concepts in the pathogenesis and treatment of chronic suppurative otitis media. J Med Microbiol.2015:1103-16.

4. Neeff M, Biswas K, Hoggard M, Taylor MW. Molecular microbiological profile of chronic suppurative otitis media. J Clin Microbiol. 2016 Oct;54(10):2538-46.

5. Adler BC. Book review: Logan turner's diseases of the nose, throat and ear., Annals Otol Rhino Laryngol. 1969;78:1317.

6. Morris P. Chronic suppurative otitis media. Am Fam Physician. 2013;88(10):694-6.

7. Asroel HA, Siregar DR, Aboet A. Profil of patient with chronic suppurative otitis media. J Public Health Policy. 2010 July;7(17):567-71.

8. Dhingra PL, Dhingra Shruti DD. Disease of ear nose and throat \& head and neck surgery. Dhingra, India: Elsevier; 2014.

9. Wahid FI, Khan A, Khan IA hma. Complications of chronic suppurative otitis media: challenge for a developing country. Kulak Burun Bogaz Ihtis Derg. 2014 May;24(5):265-70.

10. Srivastava M, Tyagi S. Bacteriological profile of chronic suppurative otitis media and its clinical significance in rural area . J Otolaryngol. 2015;5(4):1-6.

11. Master A, Wilkinson E, Wagner R. Management of chronic suppurative otitis media and otosclerosis in developing countries. Otolaryngol Clin North Am [Internet]. 2018;51(3):593-605.

12. Soepardi EA, Iskandar N, Bashiruddin J, Restuti RD. Buku ajar ilmu kesehatan telinga hidung tenggorok kepala \& leher. Edisi ke-7. Jakarta: Badan Penerbit Fakultas Kedokteran Universitas Indonesia; 2018.

13. Mediawaty D, Widodo P, Ruspita DA. Efektivitas klinis ofloksasin topikal dibanding ciprofloksasin oral pada terapi otitis media supuratif kronik aktif. Med Hosp.2017 May;4(2):77-83.

14. Sharma PC, Jain A, Jain S, Pahwa R, Yar MS Ciprofloxacin: review on developments in synthetic, analytical, and medicinal aspects. J Enzyme Inhib Med Chem. 2010;25(4):577-89.

15. Katzung BG, Masters SB, Trevor AJ. Farmakologi dasar \& klinik. Edisi ke-12. New York: Mc Graw Hill; 2012.

16. Bennett PN, Brown MJ, Sharma P. Clinical pharmacology. Edisi ke-11.China: Elsevier; 2018.

17. Bridgeman MB, Dalal KS. Pharmacology.Edisi ke6. China: Wolters Kluwer; 2015.

18. Farida Y, Oktaria D. Tatalaksana terkini otitis media supuratuf kronis (OMSK). J Medula Unila.2016 Dec;6(180):1-3.

19. Wahida N, Kadriyan H, Aini SR. Perbedaan sensitivitas bakteri penyebab otitis media supuratif kronik terhadap antibiotik siprofloksasin dan klindamisin di poli THT RSUD Provinsi NTB. J Kedokt. 2016;5(2):1-6.

20. Siddique W, Hakeem A, Ashfaq K, Khan M, Gul AA. Comparison between the efficacy of topical ciprofloxacin with neomycin in the management of chronic suppurative otitis media. Pak Armed Forces Med J. 2016;66(2):235-40.

21. Couzos S, Lea T, Mueller R, Murray R, Culbong M. Effectiveness of ototopical antibiotics for chronic suppurative otitis media in Aboriginal children: a community-based, multicentre, double-blind randomised controlled trial. Med J Aust. 2003 Aug 18;179(4):185-90.

22. Leach A, Wood Y, Gadil E, Stubbs E, Morris P. Topical ciprofloxin versus topical framycetingramicidin-dexamethasone in australian aboriginal children with recently treated chronic suppurative otitis media: a randomized controlled trial. Pediatr Infect Dis J. 2008;27(8):692-8.

23. Macfadyen C, Gamble C. Topical quinolone vs. antiseptic for treating chronic suppurative otitis media: a randomized controlled trial. Wiley Online Libr [Internet]. [diunduh 18 Oktober 20202020 Oct 18]. Tersedia dari https://onlinelibrary.wiley. com/doi/abs/10.1111/j.1365-3156.2004.01368.x

24. Kondzielewski $\mathrm{Z}$. Treatment for otitis media. CMAJ. 2005;173(3):2399-405. 